\title{
The Influence of Cigarette Designs and Smoking Regimes on Vapour Phase Yields*
}

\author{
by Steve W. Purkis ${ }^{l}$, Christian Mueller ${ }^{2}$, Michael Intorp ${ }^{2}$, and Henning Seidel ${ }^{2}$ \\ ${ }^{1}$ Imperial Tobacco Limited, PO Box 244, Southville, Bristol BS99 7UJ, England \\ ${ }^{2}$ Imperial Tobacco Group, Albert-Einstein-Ring 7, 22761 Hamburg, Germany
}

\section{SUMMARY}

Cigarettes with similar design features but with either cellulose acetate or dual carbon filters were made at 1-mg and 13-mg "tar" levels, as determined under the ISO smoking procedure. Products were smoked under the ISO, Massachusetts and Canadian smoking regimes to provide per-cigarette and per-puff yields of twelve vapour phase (VP) smoke components. The yields generated at the lit end of the cigarette and the significant yield reductions caused by filter ventilation, selective (carbon) adsorption, tobacco rod ventilation and diffusion were estimated in a modelling approach.

For a "1-mg tar" carbon-filtered product it was estimated that the VP generated at the lit end was reduced by $99.4 \%$ to a machine yield of $17 \mu \mathrm{g} / \mathrm{cig}$ under ISO smoking conditions. Under the Canadian regime with $100 \%$ vent blocking, the estimated total VP was lowered $20 \%$ by tobacco rod effects and $15 \%$ by carbon filter adsorption giving a machine yield of $3487 \mu \mathrm{g} / \mathrm{cig}$. The carbon filter adsorbed less efficiently partly due to the artificially high smoke temperatures through the filter that would probably not be tolerated by human smokers. Under the Massachusetts regime with 50\% vent blocking, conditions better associated with human smoking, the total VP was lowered $51 \%$ by filter ventilation, $22 \%$ by tobacco rod effects and $17 \%$ by carbon filter adsorption giving a machine yield of $659 \mu \mathrm{g} / \mathrm{cig}$.

Ventilation is used to achieve "tar"/nicotine/carbon monoxide yield ceilings at 10/1/10 mg based on the current ISO smoking method. If future regulations were to mandate further reductions in VP then this will only be selectively achieved by increasing filter or tobacco rod ventilation/porosity or by using selective adsorption. It is inevitable that manufacturers will need to add further ventilation into their product to comply with such regulations and this should be reflected in any smoking regime. Furthermore, regimes with 100\% vent blocking, that do not produce data reflecting the significant reductions in VP yields, provided to the smoker by ventilation, are misleading and their results will not correlate with relevant biomarker data.

When proposing a different smoking regime, it is essential to understand the generation and transfer of smoke within cigarettes and factors involved in the subsequent data interpretation as described in this work. For regulatory evaluation purposes, cigarette characterisation using a regime that removes ventilation, one of the main design tools, is more misleading than the current ISO regime or one with partial vent blocking. [Beitr. Tabakforsch. Int. 24 (2010) 33-46]

\section{ZUSAMMENFASSUNG}

Cigaretten, hergestellt auf zwei unterschiedlichen Kondensatniveaus und ausgestattet mit jeweils unterschiedlichen Filtern, einerseits einem Monoacetatfilter, andererseits einem dualen Filter mit strangseitigem Aktikohleanteil, wurden unter Anwendung unterschiedlicher Abrauchbedingungen (ISO, Massachusetts und Health Canada) auf ihre jeweiligen Gehalte an zwölf Gasphasensubstanzen untersucht. Die Messung der Gasphasensubstanzen erfolgte sowohl pro Cigarette als auch pro Zug. Mittels einer Modellrechnung wurden die signifikanten Beiträge der Filterventilation, der selektiven Adsorption durch den Kohleanteil sowie der Strangventilation und Diffusion ermittelt.

Es konnte gezeigt werden, dass unter ISO Abrauchbedingungen bei einem $1 \mathrm{mg}$-Produkt mit Kohlefilter der Gehalt an Gasphasensubstanzen im Hauptstromrauch der Cigarette bezogen auf die im Glutkegel erzeugte Menge 
um 99,4\% auf $17 \mu$ g reduziert wird. Dagegen reduziert sich die Emission der gemessenen Gasphasensubstanzen bei Anwendung des Health Canada Regimes infolge der 100\%igen Abdeckung der Filterventilation nur um 20\% durch Strangventilation bzw. Diffusion und um 15\% durch die Adsorption des Kohlefilters auf einen Gehalt von $3487 \mu \mathrm{g}$ im Hauptstromrauch. Wahrscheinlich führen die im Vergleich $\mathrm{zu}$ den anderen Abrauchbedingungen deutlich erhöhten Temperaturen in den letzten Zügen von bis $\mathrm{zu} 100{ }^{\circ} \mathrm{C}$, einer Temperatur, die für Konsumenten nicht tolerabel ist, $\mathrm{zu}$ einer artifiziell verringerten Adsorptionsleistung des Kohlefilters. Abrauchbedingungen, die dem Konsumentenverhalten näherkommen, wie das Massachussets Regime (50\% Abdeckung der Filterventilation) ergaben eine Reduzierung der Gasphasenkomponenten um 51\% durch die Filterventilation, 22\% durch Strangeffekte und 17\% durch Adsorption, was zu einer Emission von $659 \mu \mathrm{g}$ pro Cigarette führte. Im Übrigen beruhen die z.B. in der EU eingeführten Regulierungen von Kondensat, Nikotin und Carbonmonoxid auf der ISO Abrauchnorm. Sollten für Cigaretten entsprechende Regulierungen von Gasphasensubstanzen beabsichtigt werden, kann das im Wesentlichen über Maßnahmen wie Filter- und Strangventilation oder Adsorption erreicht werden. Diese Möglichkeiten sind essentiell erforderlich, um Forderungen nach weiteren Reduzierungen nachkommen zu können, und das sollte bei der Auswahl der Abrauchbedingungen berücksichtigt werden. Sollten Abrauchbedingungen mit einer 100\%igen Abdeckung der Filterventilation gefordert werden, gibt das in keiner Weise die signifikanten Reduzierungen von Gasphasensubstanzen durch die Ventilation wieder, die im Übrigen auch mit relevanten Biomarkerdaten von Konsumenten korrelieren. Bei der Auswahl eines von der ISO Norm abweichenden Rauchregimes ist es von entscheidender Bedeutung, die Entstehung und das Verhalten von Rauchemissionen und ihrer Einflussfaktoren $\mathrm{zu}$ verstehen. Die vorliegende Studie soll zum Verständnis und zur Interpretation solcher Daten beitragen. Sollte zur Regulierung von Cigarettenrauchemissionen ein Abrauchregime verwendet werden, das die Filterventilation vollständig abdeckt, sind daraus resultierende Rauchdaten irreführend im Vergleich zur ISO Abrauchnorm oder anderen Rauchregimes mit partieller Abdeckung der Ventilation. [Beitr. Tabakforsch. Int. 24 (2010) 33-46]

\section{RESUME}

Des cigarettes ayant des caractéristiques de conception comparables, mais avec un filtre en acétate de cellulose ou avec un filtre dual charbon, ont été fabriquées à deux niveaux de goudron ( $1 \mathrm{mg}$ et $13 \mathrm{mg}$ de goudron) déterminés selon le régime de fumage ISO. Les produits ont été fumés selon les régimes de fumage ISO, du Massachussetts et Canadien, pour déterminer, par cigarette et par bouffée, le rendement en douze composés de la phase vapeur de la fumée. Les rendements obtenus au niveau du dard de la cigarette et les réductions significatives causées par la ventilation du filtre, par l'adsorption sélective (charbon), par la ventilation du papier et par diffusion ont été estimés selon des modèles.
Pour un produit à $1 \mathrm{mg}$ de goudron avec filtre charbon, on a estimé que la phase vapeur générée par le dard a été réduite de $99.4 \%$, à un rendement machine de $17 \mu \mathrm{g}$ selon les conditions de fumage de l'ISO. Selon le régime Canadien, avec $100 \%$ de fermeture de la ventilation filtre, la phase vapeur qu'on a estimé générée a été réduite de $20 \%$ par les effets de la colonne tabac et de $15 \%$ par adsorption sur le filtre charbon, donnant un rendement machine de $3487 \mu \mathrm{g}$. Le filtre charbon a adsorbé moins efficacement, en partie à cause des températures artificiellement élevées de la fumée à travers le filtre qui ne seraient probablement pas tolérables pour l'homme. Selon le régime du Massachussetts, avec 50\% des trous de ventilation fermés, conditions mieux associées au fumage humain, la phase vapeur générée a été réduitede $51 \%$ par la ventilation du filtre, $22 \%$ par effet de la colonne tabac et $17 \%$ par adsorption du filtre charbon, donnant un rendement machine de $659 \mu \mathrm{g}$. La ventilation est employée pour atteindre des plafonds de rendement de goudron, nicotine et monoxyde de carbone de 10/1/10 sur la base de la méthode ISO actuelle de fumage. Si dans le future, des réglementations imposent d'autres réductions de la phase vapeur, ceci ne sera sélectivement atteignable que par l'augmentation de la ventilation filtre ou papier, ou par l'emploi d'adsorption sélective. Il est inévitable que les fabricants auront besoin d'augmenter la ventilation de leurs produits pour respecter les réglementations et que ceci devrait être reflété dans n'importe quel régime de fumage. De plus, des régimes avec $100 \%$ de fermeture des trous de ventilation qui ne produisent pas des données reflétant les réductions significatives par la ventilation des rendements de la phase vapeur fournies aux fumeurs, sont trompeurs, et les données ne seront pas corrélables aux biomarqueurs appropriés. Quand on propose un régime de fumage différent, il est essentiel de comprendre la génération et le transfert de la fumée dans la cigarette et les facteurs impliqués dans l'interprétation successive des données comme décrit dans cette étude. Dans le but d'une évaluation réglementaire, on pourrait argumenter que la caractérisation des cigarettes en se servant d'un régime qui supprime la ventilation, un des points les plus important de la conception, est plus trompeur que le régime ISO actuel, ou qu'un régime avec obturation partielle de la ventilation. [Beitr. Tabakforsch. Int. 24 (2010) 33-46]

\section{INTRODUCTION}

The current debate for an intense cigarette smoking regime for tobacco regulation has now moved towards a method primarily for product characterisation purposes $(1,2)$. TobReg, the Study Group on Tobacco Product Regulation of the World Health Organisation (WHO), still prefer the Canadian Intense (CI) regime which incorporates 100\% blocking of the filter ventilation holes, often referred to as $100 \%$ vent blocking, because they believe it will better characterise products. This is a mistake for the reasons presented throughout this report.

There are concerns that data from a machine smoking regime should be related to human smoking to some extent and this is shared by some within the tobacco regulatory community (3). If the CI regime were adopted 
incorporating $100 \%$ vent blocking then data from this regime are unlikely to correlate well with human biomarkers for VP components. Data reviewed by the ISO working group WG9, chaired by WHO, clearly showed that human smokers, even if they vent blocked either purposely or inadvertently, do not do so to the extent of $100 \%$. Vent blocking at $50 \%$ in machine smoking greatly exceeds most reported levels of human behaviour, that is, smokers tend to increase their intake by increasing puff volume and puff frequency rather than increase vent blocking (4). Conversely, if smokers do vent block, then they tend to also reduce their puff volumes.

It has also been shown that carbon filters effectively reduce vapour phase biomarkers of exposure in humans during human smoking of carbon-filtered cigarettes compared to conventional cellulose acetate-filtered cigarettes (5).

Filter ventilation is one of the design tools used by the industry to provide lower "tar"1 products under the ISO smoking regime. It is the only means of reducing vapour and particulate phase in approximately the same proportions and thus not producing an imbalance between the two phases. "Tar" reduction has been in response to product modification/yield reduction programmes established by regulatory authorities, for example, in the United Kingdom (6) and upheld by mandatory maximum yields within current international regulations (7). Cigarette designs used by the industry to achieve such yields in European brands have recently been reviewed (8).

General lowering of smoke yields can be achieved by a combination of various design parameters including increased ventilation into the paper wrapping the tobacco rod or the filter components, faster paper burn rate and lower tobacco density. "Tar" and its components including smoke nicotine can be selectively lowered by increased absorption/retention in the filter material. Smoke nicotine can also be reduced by altering nicotine levels in the blend mixtures. However, lowering of VP is limited to ventilation through the filter or tobacco rod and to selective filter adsorption and tobacco rod diffusion. In particular, filter ventilation is required to bring carbon monoxide (CO) yields down in parity with "tar" to the $10 \mathrm{mg}$ yield ceilings mandated, for example, in the European Union.

Since there is regulatory interest highlighted by TobReg in the effect of filter ventilation and selective carbon filter adsorption on machine smoking yields, then it should also be of interest to consider the contribution to yield reduction made by tobacco rod ventilation/diffusion, as described in this paper. Together they are the only cigarette design tools available to selectively reduce the VP generated at the lit end of a burning cigarette. This limited range of tools to design products giving $10 \mathrm{mg} / \mathrm{cig}$ of both "tar" and CO does not appear to be recognised by some within the regulatory arena (9). Other VP components may be subject to future regulatory ceilings (1) whilst regulations to introduce lower ignition propensity cigarettes, incorporating low porosity bands on the paper wrapping the tobacco rod, will also limit the capability of

\footnotetext{
${ }^{1}$ In this report "tar" is used to denote nicotine-free dry particulate matter (NFDPM)
}

tobacco rod ventilation and diffusion (10).

In this work, targeted VP yields were measured per-puff as well as per cigarette under three different smoking regimes. These data provide estimates of yields that were generated at the lit end of the cigarette and also provide some quantitative assessment of the contributions of various design features to VP yield reductions under different smoking regimes. These data have been used to particularly address concerns of TobReg concerning the performance of filter ventilation and adsorption in carbon filters under different smoking regimes.

\section{EXPERIMENTAL}

\section{General approach}

As with other cigarette combustion and pyrolysis products, VP components are directly generated at the lit end of the cigarette during puffing. After generation, various design features can reduce yields or alter the concentration of the smoke components delivered to the machine or to the human smoker. The smoke generated at the lit end will vary in proportion to the volume of air drawn through it, which in turn is related to the puff volume and the ventilation in the tobacco rod or filter. Once generated, the smoke travels down the tobacco rod wrapped in the cigarette paper and ambient air is drawn through the paper due to its natural porosity and permeability levels thus diluting the smoke. Some smoke components can diffuse out from the cigarette paper wrapping the tobacco rod during puffing and smouldering thus diluting the smoke still further. These tobacco rod phenomena act most effectively in the early puffs. Some of the formed smoke may distill along the tobacco rod and re-condense towards the mouth end and on later puffs may pyrolyze to form more VP. The smoke that reaches the end of the tobacco rod may be further diluted if the filter is ventilated. Conventional filter materials such as cellulose acetate (CA) retain a certain percentage of particulate phase material but VP components are only minimally retained. However, some of the smoke may be adsorbed by a filter component, giving selective filtration/adsorption such as an activated carbon portion if that is incorporated in the cigarette design. The diluted smoke finally reaches the mouth end and can be collected during machine smoking or inhaled fully or partly by the smoker.

The experimental approach was to look at the yield reductions effected by the design parameters as summarised in Figure 1:

In this modelling approach

- Machine smoke yields were measured.

- The smoke generated at the lit end was estimated from the measured yield during the last puff (where paper porosity and permeability did not affect yields) multiplied by the puff count after adjustment to $0 \%$ filter ventilation in a CA-filtered product.

- Filter ventilation levels were measured and smoke yield reductions were estimated for an unventilated product relative to the measured machine smoke yields. 


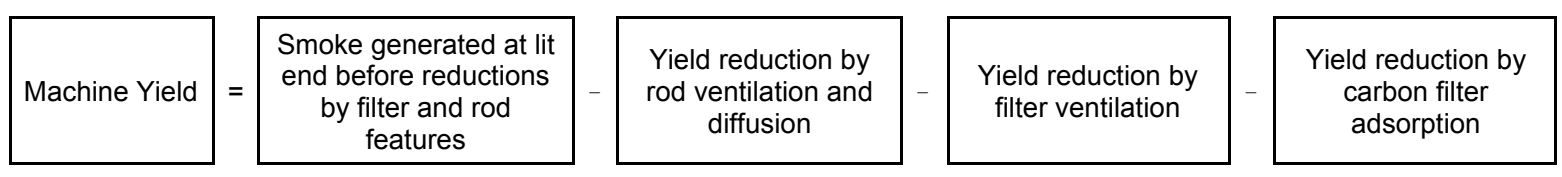

Figure 1. Yield reductions effected by various design features

- A CA-filtered product was made to match the design of a carbon-filtered product in all other respects and yields were compared between the two products. In this way, yield reductions due to carbon filter adsorption were estimated.

- Residual reductions not covered by the above design parameters were due to tobacco rod ventilation, tobacco rod diffusion and pyrolysis of condensed "tar" in the tobacco rod.

- The relative contributions of tobacco rod ventilation, tobacco rod diffusion and pyrolysis of condensed "tar" were estimated by comparing early and late puff yields in the cigarette profile.

- The estimated yields are subject to various sources of error and should be primarily used to compare relative contributions of various cigarette design characteristics rather than over-interpreting differences in absolute yields.

Products were smoked under the ISO, Massachusetts (MA) and Canadian (CI) smoking regimes using the smoking parameters described in the literature (11-13). Per-puff profiles were also obtained under the three regimes. Likewise, yield data were obtained under the three regimes for the second puff (after fully blocking the paper behind that puff with tape) and for the last puff, after the cigarette was cut to a length equivalent to two puffs. These data were used to evaluate the effects of tobacco rod ventilation/diffusion and any effects of pyrolysis of condensed "tar" on VP yields.

\section{Product descriptions}

Products are described in Table 1. Each cigarette pairing had matched cigarette weights, blends, designs and "tar" yields, to directly compare VP yields with and without carbon filters.

\section{SMOKING REGIMES AND METHODOLOGY}

Cigarettes were smoked under the three smoking regimes described in Table 2.

A 20-port smoking machine (Borgwaldt RM 20/CSR) was used for smoking the test cigarettes and the total particulate matter was collected using a 92-mm Cambridge filter pad. Cigarettes were conditioned according to ISO 3402 (14) prior to smoking and lit with a Borgwaldt electric lighter.

The VP was directed to the pump of the smoking machine and individual puffs from different cigarettes were delivered into a $500-\mathrm{mL}$ glass syringe. Immediately after smoking, $6 \mathrm{~mL}$ of the VP sample was transferred to a sample loop and injected into a gas chromatograph (GC). The individual VP components were separated on a $60 \mathrm{~m}$ Carbowax 20M GC column of $0.32 \mathrm{~mm}$ internal diameter and $0.5 \mu \mathrm{m}$ film thickness using a ramped temperature programme from 20 to $110{ }^{\circ} \mathrm{C}$ and detected by flame ionisation. A certified gas mixture of methane in nitrogen was used as the internal standard and was injected into the GC about one minute prior to sample injection.

Table 1. Specifications of the studied cigarettes. All cigarettes are American Blend Style.

\begin{tabular}{|c|c|c|c|c|}
\hline Product Description & $\begin{array}{l}\text { 1-mg "tar" } \\
\text { CA filter" }\end{array}$ & $\begin{array}{c}\text { 1-mg "tar" } \\
\text { Carbon filter }\end{array}$ & $\begin{array}{c}\text { 13-mg "tar" } \\
\text { CA filter }\end{array}$ & $\begin{array}{l}\text { 13-mg "tar" } \\
\text { Carbon filter }\end{array}$ \\
\hline Tobacco rod length (mm) & 58 & 58 & 68 & 68 \\
\hline Filter length (mm) & 25 & 25 & 25 & 25 \\
\hline Filter tipping paper (mm) & 29 & 29 & 29 & 29 \\
\hline Diameter (mm) & 7.8 & 7.8 & 7.8 & 7.8 \\
\hline Paper porosity (CORESTA Units) & 40 & 40 & 60 & 60 \\
\hline Vents open (\%) & 2.4 & 1.9 & 23.3 & 20.7 \\
\hline Vents closed (\%) & 11.0 & 15.0 & 23.3 & 20.7 \\
\hline NFDPM (mg) & 1.2 & 0.9 & 13.7 & 13.0 \\
\hline $\begin{array}{l}\text { Unblocked filter ventilation under ISO } \\
\text { smoking (\%) }\end{array}$ & 84 & 83 & 0 & 0 \\
\hline $\begin{array}{l}50 \% \text { blocked filter ventilation under MA } \\
\text { smoking }(\%)\end{array}$ & 69 & 67 & 0 & 0 \\
\hline Nicotine retention in filter (\%) & 75.4 & 83.3 & 38.8 & 39.4 \\
\hline Carbon loading per filter (mg) & 0 & 85 & 0 & 85 \\
\hline
\end{tabular}

${ }^{\text {a }} \mathrm{CA}$ filter $=$ Cellulose acetate filter

${ }^{b}$ Carbon filter dual dalmatian style 
Table 2. Smoking regime parameters

\begin{tabular}{l|c|c|c|c}
\hline $\begin{array}{l}\text { Smoking } \\
\text { regime }\end{array}$ & $\begin{array}{c}\text { Puff volume } \\
(\mathrm{mL})\end{array}$ & $\begin{array}{c}\text { Puff } \\
\text { frequency } \\
\text { (seconds) }\end{array}$ & $\begin{array}{c}\text { Puff } \\
\text { duration } \\
\text { (seconds) }\end{array}$ & $\begin{array}{c}\text { Ventilation } \\
\text { blocking } \\
(\%)\end{array}$ \\
\hline ISO & 35 & 60 & 2 & 0 \\
MA & 45 & 30 & 2 & 50 \\
CI & 55 & 30 & 2 & 100 \\
\hline
\end{tabular}

Deviations from the methane target concentration were taken into account when calculating results for vapour phase compounds. The VP yields were reported in $\mu \mathrm{g} / \mathrm{cig}$ or $\mu \mathrm{g} /$ puff. VP yields and puff counts per cigarette were determined by smoking 20 cigarettes (ISO) and 10 cigarettes (MA, CI), respectively, over one or more smoking runs and are given in Appendix 1.

\section{Total measured vapour phase components}

Initially, the sum of the yields of 12 measured VP components was determined either by smoking the full cigarette or from per-puff profiles using an in-house validated methodology. Ten of these components are required for annual emission reporting in Canada (15). Table 3 gives some $2^{\text {nd }}$ puff data under the CI regime for the four experimental cigarette types to show the level of selective adsorption by carbon before any saturation might occur. Although similar component data were also obtained for smoking under the ISO and MA regimes, the data from the intense CI regime represent the highest VP loading on the carbon and the worst case reduction obtained by carbon adsorption for the cigarettes and therefore is presented in this report.

The so-called term "Total VP" yield was estimated from the sum of the yields of 12 measured components and represented about $30 \%$ of the organic volatiles in the total area of the GC profile as measured by flame ionisation detection. The GC profile obtained by this methodology precludes the analysis of simple gases and carbon and nitrogen oxides which are also found in the VP. It can be noted in any case that carbon filters do not efficiently adsorb carbon oxides.

Different $\%$ reductions by the carbon filter were found for different VP components. Although not shown in this re- port, it was checked that the conclusions made, based on the total VP yields, were also made when individual components, such as acetaldehyde and isoprene that give quite different reductions ( $28 \%$ versus $63 \%$, respectively), were studied individually.

\section{Per-puff smoking runs}

For each cigarette type, 20 cigarettes had been previously smoked down to the ISO butt length to evaluate the puff count. The puffs collected for per-puff analysis were always taken as complete $35-$, $45-$ or $55-\mathrm{mL}$ puffs. If a cigarette had a puff count of 7.9 then only 7 individual puffs were taken into account for per-puff analysis. For the graphical plots in Appendices 2-7, puff numbers were normalised to percentage of cigarette burnt to account for the full puff number where $100 \%$ of the cigarette burnt was equivalent to smoking down to the butt length.

Per-puff profiles were obtained from the 4 experimental cigarettes. Fourteen cigarettes were loaded into the rotary smoking machine. VP was delivered to a glass syringe of total volume $650 \mathrm{~mL}$ and the valve was opened at the respective puff number. Each of the 14 cigarettes in turn rotated into the puffing position. For each puff, the VP from the first 4 cigarettes was used to clean/purge the machine and then discarded. The inlet into the glass syringe was then opened and smoke from the $5^{\text {th }}$ up to the $14^{\text {th }}$ cigarette was collected for analysis. Following this procedure, individual puffs of 10 cigarettes were collected for analysis during each smoking run. VP yields per-puff are given in Appendix 1.

\section{Smoking the last cigarette puff equivalent on a "cut-off" cigarette}

In this experiment, prior to smoking, cigarettes were cut off to a length equivalent to the last two full puffs plus the butt length. Data from the lighting puff is often higher and atypical of other puffs (16) and so this puff was smoked then discarded; instead the VP from the puff after the lighting puff was measured in this experiment. Cut-off cigarettes were smoked under the three regimes and total VP yields from the last puff are given in Appendix 1. Data will be referred to as the last "cut-off" puff.

Table 3. VP yields from the $2^{\text {nd }}$ puff obtained under $\mathrm{Cl}$ smoking regime $\left(\mu \mathrm{g} / 2^{\text {nd }}\right.$ puff of per-puff profile).

\begin{tabular}{|c|c|c|c|c|c|c|}
\hline $\begin{array}{l}\text { Vapour-phase } \\
\text { components }\end{array}$ & $\begin{array}{c}\text { 13-mg "tar" } \\
\text { CA filter }\end{array}$ & $\begin{array}{l}13 \mathrm{mg} \text { "tar" } \\
\text { Carbon filter }\end{array}$ & $\begin{array}{c}\text { Reduction } \\
(\%)\end{array}$ & $\begin{array}{c}\text { 1-mg "tar" } \\
\text { CA filter }\end{array}$ & $\begin{array}{l}\text { 1-mg "tar" } \\
\text { Carbon filter }\end{array}$ & $\begin{array}{c}\text { Reduction } \\
(\%)\end{array}$ \\
\hline Butadiene & 11.26 & 9.18 & 10 & 15.40 & 11.28 & 27 \\
\hline Isoprene & 63.78 & 37.52 & 63 & 111.52 & 39.30 & 65 \\
\hline Acetaldehyde & 138.75 & 99.81 & 28 & 178.00 & 103.86 & 43 \\
\hline Acetone & 52.07 & 23.14 & 55 & 62.45 & 21.29 & 66 \\
\hline Acrolein & 11.87 & 5.42 & 55 & 17.15 & 5.44 & 69 \\
\hline Methanol & 33.02 & 14.58 & 55 & 42.90 & 16.88 & 61 \\
\hline Benzene & 8.76 & 3.24 & 64 & 11.81 & 3.21 & 73 \\
\hline Acrylonitrile & 3.48 & 1.27 & 64 & 5.51 & 1.43 & 75 \\
\hline Acetonitrile & 15.67 & 7.59 & 51 & 22.28 & 7.27 & 67 \\
\hline Hydrogen cyanide & 22.29 & 15.11 & 32 & 44.44 & 15.85 & 64 \\
\hline Toluene & 15.31 & 4.23 & 73 & 18.83 & 3.75 & 80 \\
\hline Styrene & 1.49 & 0.43 & 73 & 1.52 & 0.06 & 96 \\
\hline Total vapour phase & 377.7 & 221.5 & 41 & 531.8 & 229.6 & 57 \\
\hline
\end{tabular}


VP yields from the last "cut-off" puff, where tobacco rod ventilation and diffusion cannot have any appreciable effect, were used to estimate the smoke concentration generated at the lit end. This was carried out under each of the three smoking regimes where the puff volumes were 35-, 45- and 55-mL respectively. Smoke VP yields for the unventilated 13-mg "tar" products with the CA filter are taken from Appendix 1 and VP concentrations are summarised in Table 4.

Table 4. VP concentrations per $\mathrm{mL}$ smoke generated at the lit end (VP concentration at the lit end = VP yield for last puff/(puff volume))

\begin{tabular}{l|c|c|c}
\hline \multirow{2}{*}{ Regime } & \multirow{2}{*}{$\begin{array}{c}\text { Puff } \\
\text { volume } \\
\end{array}$} & $(\mathrm{mL})$ & \multicolumn{2}{|c}{$\begin{array}{c}\text { Total VP from 13-mg "tar" CA-filtered } \\
\text { products }\end{array}$} \\
\cline { 3 - 4 } & & $\begin{array}{c}\text { yield for last } \\
\text { "cut-off" puff }(\mu \mathrm{g})\end{array}$ & $\begin{array}{c}\text { VP concentration } \\
\text { at lit end }(\mu \mathrm{g} / \mathrm{mL})\end{array}$ \\
\hline ISO & 35 & 393 & 11.2 \\
MA & 45 & 519 & 11.5 \\
Cl & 55 & 649 & 11.8 \\
\hline
\end{tabular}

\section{Smoking the second puff after blocking paper ventilation}

Again, the puff after the lighting puff was considered in this experiment. Prior to smoking, the cigarette was left untaped at the mouth end for a length equivalent to the first two puffs plus $5 \mathrm{~mm}$. The rest of the tobacco rod was taped with non-porous self-adhesive tipping paper in order to eliminate ventilation and diffusion effects. The taped cigarettes were smoked under the three regimes and total VP yields from the second puff are given in Appendix 1. Data will be referred to as the $2^{\text {nd } ~ " t a p e d " ~ p u f f . ~}$

\section{Smoke temperature effects and re-smoking with "used" carbon filters}

This work investigated whether it were possible that VP was reduced by carbon filters not working efficiently in the last few puffs. This could be due to a combination of reduced carbon filter adsorption efficiency or carbon desorption caused by an elevated temperature of smoke passing through the filter, as well as saturation of the active adsorption sites within the carbon, rather than simply the latter.

Two replicates of the 1-mg NFDPM CA-filtered products were smoked on a single-port Borgwaldt cigarette smoking machine under ISO and CI regimes. A resistor based temperature sensor wire (Almemo PT100) was inserted either $5 \mathrm{~mm}$ or $20 \mathrm{~mm}$ from the mouth end through the tipping paper into the side of the filter and the temperature monitored over during the puff profile. The position at
$20 \mathrm{~mm}$ from the mouth end was equivalent to the position within the carbon-containing section of a carbon-filtered product and at $5 \mathrm{~mm}$ was very close to the mouth end. A tight fit was required to prevent introduction of ventilation into the filter and so the detector was inserted in one movement. Minimum temperatures were recorded just before a puff was taken and maximum recorded around 2 seconds after the start of the puff. Results from the two replicates were very similar but only results from the $2^{\text {nd }}$ replicate are plotted in Appendices 8 and 9 for the two filter measurement positions because puff numbers differed. It was noted that puff numbers were probably higher in this experiment relative to those provided in Appendix 1 due to the uncontrolled air flow around this smoking machine.

Temperature measurements on 1-mg NFDPM carbonfiltered products, $20 \mathrm{~mm}$ from the mouth end (equivalent to within carbon section) were also measured as shown in Table 5 .

It can be noted that the experimental carbon-filtered cigarettes prepared for this study were completely consumed during this work and measurements under the MA smoking regime and temperatures measured $5 \mathrm{~mm}$ from the mouth end were not performed. However, it can be seen that temperatures within both CA- and carbonfiltered cigarettes were very similar across the profile.

Ten cigarettes of both the 1-mg CA- and carbon-filtered products were smoked over 2 smoking runs under the CI regime and gave smoke VP yields and puff numbers shown in Table 6 similar to those initially obtained in earlier runs provided in Appendix 1. After smoking, the "used" carbon filter tips were detached and then reattached with self adhesive tape to tobacco rods from the unsmoked cigarettes of the same type on the following day. These cigarettes were re-smoked a day later. The VP yield data were used to determine whether the "used" carbon filters could still remove additional VP by comparing yields with those given by original carbon- and CAfiltered cigarettes re-smoked at the same time.

\section{Smoke nicotine yields}

In this experiment, prior to smoking, cigarettes were cut off to a length equivalent to two full puffs plus the butt length. 20 "cut-off" cigarettes were smoked under ISO regime and 10 "cut-off" cigarettes under the CI regime. Smoke particulate phase was collected on a 44-mm Cambridge filter pad to reduce solvent extraction volume. For each regime, one run was smoked to determine the nicotine yield from the last two puffs and a further run was smoked to determine the nicotine yield from the penultimate puff only.

Table 5. Per-puff temperature profile for the 1-mg "tar" CA-filtered product

\begin{tabular}{|c|c|c|c|c|c|c|c|c|c|c|c|}
\hline \multirow{2}{*}{$\begin{array}{l}\text { Smoking } \\
\text { regime }\end{array}$} & \multirow{2}{*}{$\begin{array}{c}\text { Temperature } \\
\left({ }^{\circ} \mathrm{C}\right)\end{array}$} & \multicolumn{10}{|c|}{$\%$ Cigarette burnt } \\
\hline & & 10 & 20 & 30 & 40 & 50 & 60 & 70 & 80 & 90 & 100 \\
\hline \multirow{2}{*}{ ISO } & minimum & - & 24 & 24 & 24 & 24 & 24 & 24 & 24 & 29 & 37 \\
\hline & maximum & - & 24 & 24 & 24 & 24 & 24 & 24 & 25 & 37 & 70 \\
\hline \multirow{2}{*}{$\mathrm{Cl}$} & minimum & - & 24 & 24 & 26 & 28 & 33 & 42 & 47 & 45 & 51 \\
\hline & maximum & - & 24 & 28 & 29 & 40 & 60 & 67 & 59 & 68 & 101 \\
\hline
\end{tabular}


Table 6. Comparison of total VP yields under $\mathrm{Cl}$ smoking regime made from cigarettes with various filters attached

\begin{tabular}{lcc}
\hline Product & $\begin{array}{c}\text { Total VP } \\
\text { yield }(\mu \mathrm{g} / \mathrm{cig})\end{array}$ & Puff Number \\
\hline 1-mg "tar" CA Filter & 4498 & 7.25 \\
1-mg "tar" Carbon Filter & 3468 & 7.55 \\
1-mg "tar" "used" Carbon Filter & 3785 & 7.81 \\
\hline
\end{tabular}

Smoke nicotine yields from 1-mg "tar" CA-filtered cigarettes were determined for the last puff under ISO and CI smoking regimes by subtracting the latter from the former yields. In this way, concentrations of VP per mg smoke nicotine generated in the last puff, equivalent to that generated at the lit end, were compared to concentrations given as machine yields under both regimes, as shown in Table 7.

\section{RESULTS AND DISCUSSION}

"Total VP" yields per cigarette, from the per-puff profiles and from the 2nd "taped" and last "cut-off" puffs are given in Appendix 1. Per-puff yield profiles under different smoking regimes are represented graphically in Appendices 2-7 and per-puff temperature profiles in the filter are represented graphically in Appendices 8-9. Estimates of absolute and relative reductions caused by the various cigarette design features under the different smoking regimes, as described in Figure 1, are summarised in Appendices 10-11.

Relationship of yield to volume of smoke generated at the lit end

The smoke concentrations generated at the lit end, shown in Table 4 , were very similar for all three regimes. This confirms that the volume of air passing through the lit end is directly related to the generation and smoke concentration of these VP components.

Vapour phase yields generated at the lit end under different smoking regimes

To estimate the "Total VP" yield generated at the lit end in a CA-filtered, unventilated product, the measured yield from the last "cut-off" puff of the cigarette, where no tobacco rod effects operated, was multiplied by the number of puffs given by the cigarette under normal machine smoking conditions then adjusted to $0 \%$ filter ventilation. These estimates are given in Appendices 10 and 11 and demonstrate the increase in generated smoke as the smoking regime intensity increased. Reductions by various design features were compared against these initially generated yields.

\section{Role of ventilation and diffusion along the tobacco rod and filter tip}

A reduction in the number of ventilation holes by $50 \%$ does not reduce the effective ventilation by $50 \%$ (17). For the 1-mg "tar" product studied in this work, filter ventilation levels using a $17.5 \mathrm{~mL} / \mathrm{sec}$ flow rate with $0 \%$ vent blocking were found to be $\sim 84 \%$ and with $50 \%$ vent blocking were $67-69 \%$, as shown in Table 1 . The flow rate used for all ventilation measurements was equivalent to that used during ISO smoking. Using such data seemed acceptable since literature data (18) suggested that ventilation is reduced very little by increasing the flow rate to $22.5 \mathrm{~mL} / \mathrm{sec}$ as applied in the MA smoking regime. Therefore, an estimated level of $65 \%$ filter ventilation was used in calculations relating to the MA regime.

Measurement of both the VP yield per cigarette and the $\%$ filter ventilation allowed an estimate of the theoretical yield per cigarette, when correcting to $0 \%$ ventilation. This allowed an estimate of the contribution of tobacco rod ventilation/diffusion to overall VP reduction in an unventilated product. The means of calculation and the yield reductions for the various products are given in Appendix 10 and are represented graphically in Appendix 11. It is clear that significant VP reductions $(51 \%)$ relative to the amount generated at the lit end were made by ventilation even with $50 \%$ vent blocking.

Taking account of the limitations due to measurement uncertainty in this type of experiment, the yield from the last puff of the CA-filtered products, obtained from the per-puff profiles, was generally not too dissimilar to those yields obtained from the last "cut-off" puff. This suggested that relatively low amounts $(<5 \%)$ of VP were generated by condensation/re-pyrolysis along the tobacco rod during the normal smoking process. The yield from the $2^{\text {nd }}$ "taped" puff, for each cigarette type, was slightly lower than that from the last "cut-off" puff suggesting that some condensation/re-pyrolysis or diffusion may have occurred especially under a low flow rate through the cigarette during ISO smoking regime.

Table 7. Measured VP and nicotine concentrations in $1 \mathrm{mg}$ "tar" CA-filtered cigarettes ( $\mu \mathrm{g} / \mathrm{mg}$ smoke nicotine)

\begin{tabular}{|c|c|c|c|c|c|}
\hline Regime & Smoke component & Yield from last puff & Machine yield & \begin{tabular}{|c|} 
VP/smoke nicotine in \\
last puff $(\mu \mathrm{g} / \mathrm{mg})^{\text {a }}$
\end{tabular} & \begin{tabular}{|c|}
$\mathrm{VP} / \mathrm{smoke}$ nicotine \\
machine yields $(\mu \mathrm{g} / \mathrm{mg})$
\end{tabular} \\
\hline ISO & $\begin{array}{l}\text { Nicotine }(\mathrm{mg}) \\
\operatorname{VP}(\mu \mathrm{g})\end{array}$ & $\begin{array}{c}0.023 \\
57\end{array}$ & $\begin{array}{c}0.14 \\
179\end{array}$ & 2478 & 1279 \\
\hline $\mathrm{Cl}$ & $\begin{array}{l}\text { Nicotine }(\mathrm{mg}) \\
\quad \operatorname{VP}(\mu \mathrm{g})\end{array}$ & $\begin{array}{l}0.238 \\
747\end{array}$ & $\begin{array}{r}2.02 \\
4262\end{array}$ & 3138 & 2110 \\
\hline
\end{tabular}

${ }^{a}$ equivalent to that generated at the lit end 
Unlit tobacco rod ventilation values were measured at around $22 \%$ for the $13-\mathrm{mg}$ "tar" unventilated products. For a paper with similar porosity $(60 \mathrm{CU})$, tobacco rod ventilation was previously reported to be higher $(>30 \%)$ in the early puffs after the cigarette was lit but was then much reduced $(10-15 \%)$ in the later puffs (19). Unlit values of around $2 \%$ with filter vents open and around $13 \%$ with vents closed were measured for the studied 1-mg "tar" ventilated products.

From data in Appendix 10, the VP yield reduced by a combination of tobacco rod ventilation and diffusion compared to that produced at the lit end for the CA-filtered 13-mg "tar" product under ISO smoking was estimated to be $32 \%$. This compares to the discussed measurements in the literature (19). However, for the CA-filtered 1-mg "tar" product, the yield lost to tobacco rod ventilation and diffusion was estimated to be $61 \%$ after adjusting to the unventilated filter state. This was significantly higher than that simply predicted from measured tobacco rod ventilation and suggested significant tobacco rod diffusion particularly at these lower flow rates through the cigarette during ISO smoking.

For each cigarette type, the yield from the $2^{\text {nd }}$ "taped" puff was significantly higher than the $2^{\text {nd }}$ puff from the per-puff profiles. This again suggested that substantial VP components were lost by both ventilation and diffusion during the smoking process. Other workers have reported that ventilated cigarettes gave lower carbon monoxide (CO) concentrations than would be predicted by air dilution alone and that reduction resulted primarily from increased $\mathrm{CO}$ diffusion through the cigarette paper as the velocity of the mainstream smoke was lowered by filter ventilation (20).

In summary, the data show that condensation/re-pyrolysis does not appear to have a major effect on yields and that diffusion through the paper, in addition to tobacco rod ventilation, must be playing a significant role in VP reduction especially in ventilated products, in a similar way to the $\mathrm{CO}$ effects described in the literature.

\section{Role of carbon filters in absolute yields reductions}

Alongside ventilation, carbon filter adsorption can be used to reduce the levels of VP components and occurs after VP has already been reduced by tobacco rod ventilation and diffusion following smoke generation at the lit end.

As an example, yields from the 1-mg "tar" product were compared under ISO smoking in products with and without carbon filter adsorption (Appendix 10). The carbon filter removed $162 \mu \mathrm{g} / \mathrm{cig}$ of $\mathrm{VP}$, reducing yields from $179 \mu \mathrm{g}$ to $17 \mu \mathrm{g}$ but this reduction represented just $6 \%$ of the VP generated at the lit end $(2850 \mu \mathrm{g})$. By that stage $1745 \mu \mathrm{g}$ had already been removed by tobacco rod effects and a further $926 \mu \mathrm{g}(32 \%)$ by filter ventilation.

For the MA smoking regime, carbon filter adsorption removed $1096 \mu \mathrm{g} / \mathrm{cig}$ reducing VP yields from $1755 \mu \mathrm{g}$ to $659 \mu \mathrm{g}$. By the time the smoke entered the filter $1415 \mu \mathrm{g}$ had already been removed by tobacco rod effects and a further $3259 \mu \mathrm{g}$ by filter ventilation even with $50 \%$ vent blocking. It has been demonstrated recently (21) that data from smoking low "tar" products under the MA regime reflect the mean in-use human data. Even if smokers inhale larger puff volumes than the $45 \mathrm{~mL}$ used under the MA regime, then these high percentage reductions by filter ventilation will still occur.

Under the CI smoking regime, carbon filter adsorption reduced VP yields from $4262 \mu \mathrm{g} / \mathrm{cig}$ to $3487 \mu \mathrm{g} / \mathrm{cig}$ when $974 \mu \mathrm{g}$ had already been removed by tobacco rod effects. Even under these intense conditions, unlikely to be experienced by most smokers, the carbon filter still removed substantial amounts of VP, five times more than under ISO smoking and, depending on the limits of the measurement accuracy, similar amounts to that removed under MA smoking.

\section{Effect of carbon filter adsorption over the puff profile}

There was a fairly constant per-puff reduction in VP when comparing the carbon-filtered products with the CAfiltered products over the first few puffs (Appendices 2-3 and 5-7). However, the adsorption by the carbon in the filter then significantly declined in the later puffs (indicated by convergence of the two yield profiles).

For the 13-mg "tar" products smoked under the ISO regime, it was only in the last puff that the per-puff yield profiles started to converge (see Appendix 2). In total, $884 \mu \mathrm{g} / \mathrm{cig}$ was removed by carbon giving a $28 \%$ reduction compared to the yield generated at the lit end. When the same products were smoked under the CI regime, the carbon filter removed a fairly constant amount of VP perpuff until puff 6 after which there was a decreasing reduction. In the first 6 puffs, $924 \mu \mathrm{g}$ was removed i.e. during the smoking of the first $50-60 \%$ of the cigarette and $1059 \mu \mathrm{g}$ over the full puff profile.

The two per-puff yield profiles for the 13-mg "tar" products tended to converge and even crossed over under CI smoking (see Appendix 3). Whilst these data initially look anomalous, they can be explained by desorption of the VP already trapped on the carbon due to the high smoke temperature. The percentage of VP adsorbed within the carbon filters when compared to the machine yields of CA-filtered cigarettes is tabulated in Appendix 1 and plotted in Appendix 4. It shows negative adsorption (desorption) in the later puffs under CI smoking. This desorption is in contrast to the VP adsorption in the last "cut off" puff under CI smoking where no VP had previously adsorbed on to the carbon. The percentage adsorption lay in the expected per-puff position shown by the extrapolated line in Appendix 4.

For the 1-mg "tar" carbon-filtered product under ISO smoking (Appendix 5), the carbon filter removed $162 \mu \mathrm{g} / \mathrm{cig}$ of VP in a very efficient manner during each puff. Similarly under MA smoking (Appendix 6), $1096 \mu \mathrm{g}$ of VP was removed with a hint of convergence of the two per-puff profiles. When this product was smoked under the CI regime, the carbon filter removed a fairly constant amount of VP per-puff over the first 4 puffs. In fact, $1129 \mu \mathrm{g}$ was removed in the first $50 \%$ of the cigarette, after which the two per-puff profiles tended to converge (Appendix 7). Several references in a recent review (4) show how, generally, smokers tend to smoke more intensively in the first few puffs, the part of the cigarette where carbon filters are adsorbing VP more efficiently. 
Measurements on temperature of smoke passing through the carbon filter

The particular carbon filter used in these 1-mg and 13-mg "tar" products and under the three smoking regimes appeared to adsorb around $1000 \mu \mathrm{g}$ VP before it became less effective. This might suggest that in the later puffs there was a loss of carbon activity or that the amount of carbon within the filter was fully loaded with adsorbed VP and water. However, temperature data given in Appendix 8 have shown that some of this apparent saturation is allied to the intensity of the smoking regime where the higher temperature of the smoke passing over the carbon at high flow rates in the later puffs prevented carbon filter adsorption from working efficiently. The per puff temperature measurements given in Appendix 8 strongly demonstrate the elevated temperature of smoke passing through the carbon filter during CI smoking compared to ISO smoking.

If the high temperatures $\left(>60{ }^{\circ} \mathrm{C}\right)$ near the mouth end over the last few puffs (see Appendix 9) were evident during human smoking then they would probably not be tolerated by smokers and their puffing behaviour would change. In addition, as the smoke temperature increases so the smoke viscosity increases, leading to higher pressure drop and draw resistance during smoking. These effects would also tend to decrease human smoking intensity.

\section{Measurements on cigarettes where the fresh carbon filter had been replaced by a smoked carbon filter}

1-mg "tar" carbon-filtered cigarettes were smoked under CI conditions then the filters were detached from the remaining butt and re-attached onto fresh tobacco rods. VP yields under CI smoking are given in Table 6 from 1-mg "tar" cigarettes made from these re-attached carbon filters onto fresh tobacco rods. Results suggested that carbon filters were not overloaded and retained the capacity to remove further VP $(>500 \mu \mathrm{g})$ before again being exposed to the artificially high smoke temperatures in the later puffs.

\section{Vapour phase yields per mg smoke nicotine}

During intense smoking with $100 \%$ vent blocking, VP components such as $\mathrm{CO}$ were not removed by filter retention, whereas nicotine continued to be efficiently and selectively removed. These effects have been previously well described (17). Inevitably, yields expressed as VP concentrations per mg smoke nicotine increased under the CI regime compared to the ISO regime (from 1279 to $2110 \mu \mathrm{g} / \mathrm{mg}$ ) as shown in Figure 8 for the $1-\mathrm{mg}$ "tar" ISO product with a CA filter. Such increases would not be found using a smoking regime with less vent blocking, more associated with human smoking.

\section{CONCLUSIONS}

Relatively high amounts of VP are generated at the lit end compared to levels collected in mainstream smoke. The volume of air passing through the lit end is directly related to the levels of VP components generated in the lit end of the cigarette. As such, a greater amount of VP was clearly produced under the $\mathrm{CI}$ regime but, due to the improbable $100 \%$ vent blocking, these VP yields may far exceed human smoking intake.

Relatively low levels of VP were generated by condensation/pyrolysis along the tobacco rod compared to those levels generated at the lit end, but significant reductions were achieved by tobacco rod ventilation and diffusion during smoking. Absolute yields of cigarette VP components were then reduced further by other design features such as carbon filter adsorption and filter ventilation.

Filter ventilation removed considerably more VP during intense rather than ISO smoking, except when $100 \%$ vent blocking occurred. Reductions caused by filter ventilation, relative to the amount produced at the lit end in an unventilated cigarette, were considerable and well exceeded the measured machine smoking yields. Thus, the CI approach to characterise the smoke from a product after removing one of its main design features appears to be seriously misleading.

Different cellulose acetate and carbon filter designs will have different removal efficiencies for particulate and VP components. The particular carbon filter studied in this work appeared capable of removing around $1000 \mu \mathrm{g}$ VP and did not overload when smoking under ISO and MA regimes. Even when smoking the 1-mg "tar" product under the CI regime, the carbon filter removed five times more VP than under the ISO regime.

However, the high temperature under the extreme CI smoking conditions caused less VP adsorption onto the carbon and even some desorption in the later puffs rather than total saturation of the active carbon adsorption sites in the filter. Indeed, the temperature of the smoke passing through the filter is so significantly higher under CI smoking that it is unlikely to be tolerated by human smokers.

VP was not retained by CA filters under any smoking conditions. However, under CI compared to ISO smoking, more nicotine was selectively removed by filter retention and no VP removed due to $100 \%$ vent blocking. So, yields expressed as VP per mg smoke nicotine increased under the CI regime.

Removing the effects of ventilation, as in the CI regime, will severely distort compliance with potential ceilings on VP concentrations per mg nicotine and will also bias against certain brand styles with lower than average smoke nicotine yields. It is also clear that significant VP reductions $(51 \%)$ relative to that generated at the lit end were made by filter ventilation even with $50 \%$ vent blocking. These issues need to be taken into account if it were intended to relate machine smoking data to human biomarker studies and particularly to comply with regulatory proposals to reduce smoke VP concentrations per mg smoke nicotine (1).

On the basis of this data, it appears to be even more misleading to use the CI rather than either the ISO or MA regime for regulatory evaluation purposes. It remains necessary to define well both the short-term and long-term objectives for using any new smoking regime and analyse the created distortions to human smoking before undue 
reliance is placed upon the data obtained from any such regime, particularly for regulatory purposes.

\section{REFERENCES}

1. Burns, D.M., E. Dybing, N. Gray, S.S. Hecht, C. Anderson, T. Sanner, R. O'Connor, M.V. Djordjevic, C. Dresler, P. Hainaut, M. Jarvis, A. Opperhuizen, and K. Straif: Mandated lowering of toxicants in cigarette smoke: A description of the WHO TobReg proposal; Tob. Control 17 (2008) 132-141.

2. TobReg: The scientific basis of tobacco product regulation; Report of a WHO Study Group (TobReg); WHO Technical Report Series 945, 2007.

3. Hammond, D., F. Wiebel, L.T. Kozlowski, R. Borland, K.M. Cummings, R.J. O’Connor, A. McNeill, G.N. Connolly, D. Arnott, and G.T. Fong: Revising the machine smoking regime for cigarette emissions: Implications for tobacco control policy; Tob. Control 16 (2007) 8-14.

4. Pickworth, W., P. Houlgate, M. Schorp, M. Dixon, M.F. Borgerding, and G. Zaatari: A review of human smoking behaviour data and recommendations for a new ISO standard for machine smoking of cigarettes; Report of the Ad Hoc WG9 smoking behaviour review team to ISO/TC 126 WG9 2005,

see http://legacy.library.ucsf.edu/tid/mgt27a00 (accessed April 2010)

5. Scherer, G., M. Urban, J. Engl, H.-W. Hagedorn, and K. Riedel: Influence of smoking charcoal filter tipped cigarettes on various biomarkers of exposure; Inhal. Toxicol. 18 (2006) 821-829.

6. Waller, R.E. and P. Froggatt: Product modification; Brit. Med. Bull. 52 (1996) 193-205.

7. European Commission Directive: On the approximation of the laws, regulations and administrative provisions of the Member States concerning the manufacture, presentation and sale of tobacco products; 2001/37/EC of the European Parliament and of the Council 5 June 2001.

8. LeMoigne, C., D. Raverdy-Lambert, N. Tardif, J.M. Loureau, and G. LeBourvellec: Market survey: Study on the cigarette design used in Europe; CORESTA Congress, 2007, Jeju, Korea Abstr. SSPT 02, p. 16, see http://www.coresta.org/Past_Abstracts/Jeju2007SmokeTech.pdf (accessed April 2010)

9. O’Connor, R.J., K.M. Cummings, A. McNeill, and L.T. Kozlowski: How did UK cigarette makers reduce tar to $10 \mathrm{mg}$ or less?; Brit. Med. J. 332 (2006) 302.

10. European Commission Report: Draft standardisation mandate to CEN relating to the fire safety requirement for cigarettes; Document 32/2008-EN $4^{\text {th }}$ May 2008.

11. ISO Standard 3308: Routine analytical smoking machine - Definition and standard conditions; International Organisation for Standardisation, Geneva 2000.

12. Borgerding, M.F., J.A. Bodnar, and D.E. Wingate: The 1999 Massachusetts Benchmark Study - Final Report; presented to the Massachusetts Department of Public
Health $24^{\text {th }}$ July 2000 ,

see http://legacy.library.ucsf.edu/tid/yek21c00 (accessed April 2010)

13. Health Canada: Determination of "Tar", Nicotine and Carbon Monoxide in Mainstream Tobacco Smoke; see http://www.hc-sc.gc.ca/hc-ps/alt_formats/hecs-sesc/ $\mathrm{pdf} /$ tobac-tabac/legislation/reg/indust/method/ main-principal/nicotine-eng.pdf (accessed April 2010)

14. ISO 3402: Tobacco and tobacco products - Atmosphere for conditioning and testing; International Organisation for Standardisation, Geneva 1999.

15. Health Canada methods, see http://www.hc-sc.gc.ca/hc-ps/tobac-tabac/legislation/ $\mathrm{reg} /$ indust/method/index-eng.php\#main (accessed April 2010)

16. Wagner, K.A., R. Higby, and K. Stutt: Puff by puff analysis of selected mainstream smoke constituents in the Kentucky Reference 2R4F cigarette; Beitr. Tabakforsch. Int. 21 (2005) 273-279.

17. Baker, R.R., M. Dixon, and C. Hill: The incidence and consequence of filter vent blocking amongst British smokers; Beitr. Tabakforsch. Int. 18 (1998) 71-83.

18. Mathis, D.: Flow rate dependence of ventilation; Beitr. Tabakforsch. Int. 14 (1987) 11-19.

19. Dashley, F.: Simultaneous puff by puff filter and tobacco rod ventilation measurements; BAT Report, 1980, RD 1768 in Legacy Tobacco Documents Library, Bates number 570521653/1696

20. Morie, G.P.: Some factors that affect the diffusion of carbon monoxide out of cigarettes; Tob. Sci. 20 (1976) 174-176.

21. Mariner, D.C., M. Booty, G. Mullard, and C.J. Shepperd: A comparison of German smokers' exposure to tar and nicotine using analysis of smoked cigarette filters with yields from a range of machine smoking regimes; Poster presented at the 9th Annual European Meeting of the Society for Research on Nicotine and Tobacco, Madrid, Spain, October 3-6, 2007, see

http://www.bat-science.com/groupms/sites/bat_7awf h3.nsf/vwPagesWebLive/DO7AXGPQ/\$FILE/medM D7DTCV7.pdf?openelement (accessed April 2010)

\section{ACKNOWLEDGEMENTS}

The authors wish to thank Ragna Ortlepp, Claudia John, Ute Grezuweit, Silvia Wolf and Sandra Kudszus for sample preparation, smoke analysis and providing practical solutions to address issues discussed in this report.

\section{Corresponding author:}

\section{S.W. Purkis}

Imperial Tobacco Limited,

PO Box 244, Southville,

Bristol BS99 7UJ, England

E-mail: steve.purkis@uk.imptob.com 


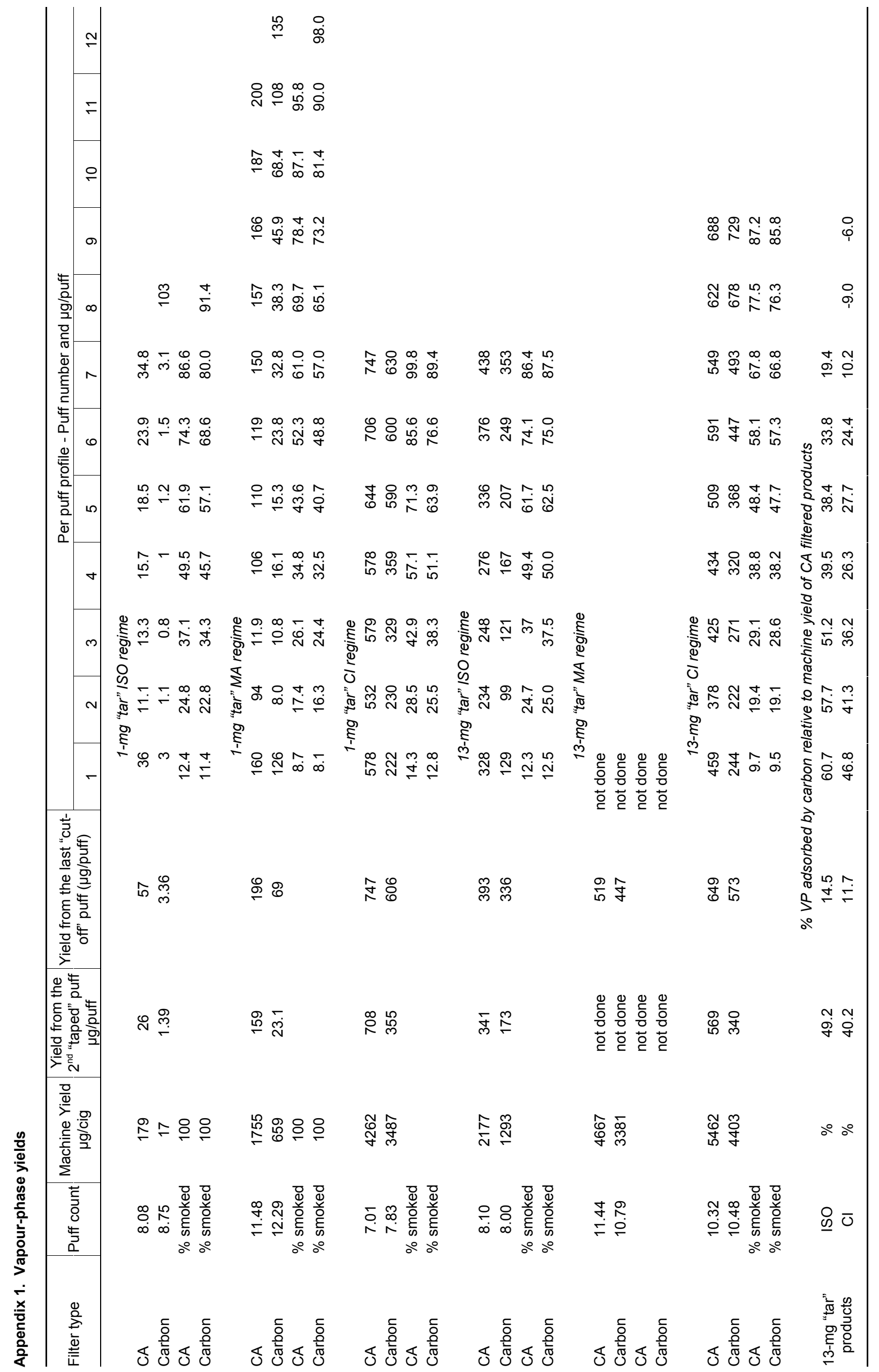




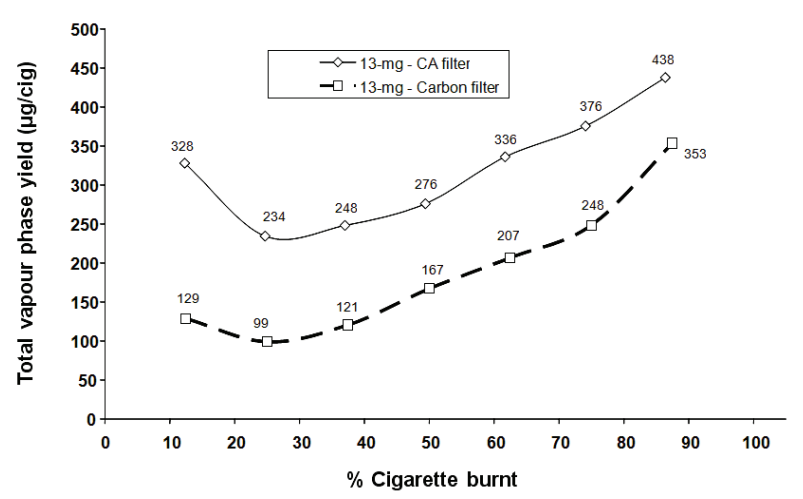

Appendix 2. 13-mg "tar" (ISO) products smoked under ISO regime

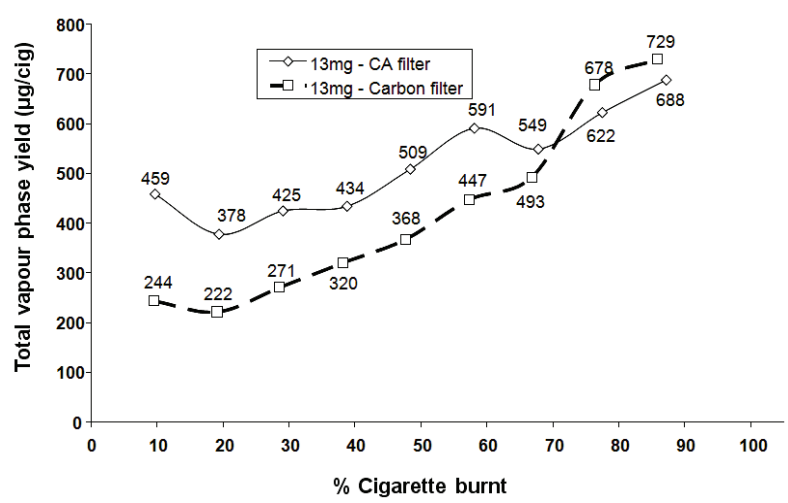

Appendix 3. 13-mg "tar" (ISO) products smoked under CI regime

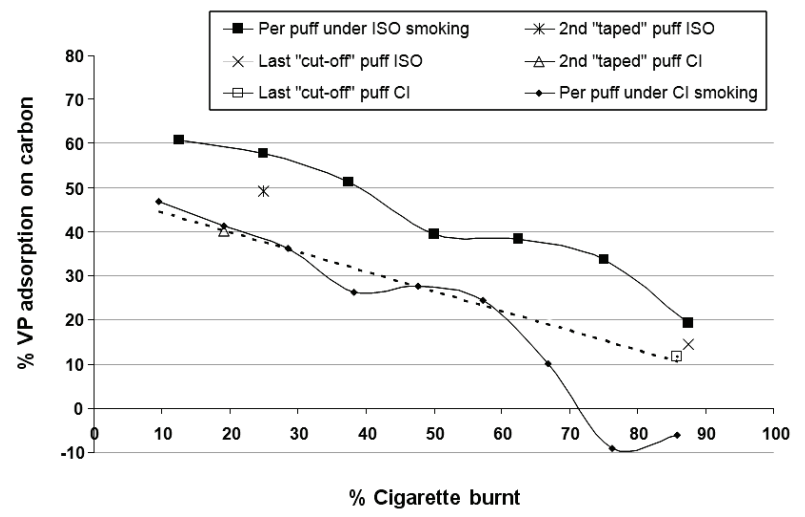

Appendix 4. Vapour-phase adsorption in carbon filters for 13-mg "tar" (ISO) products

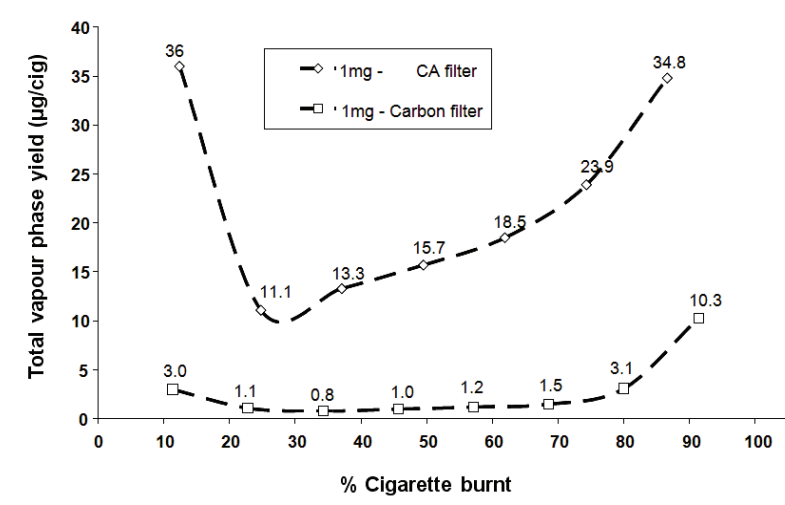

Appendix 5. 1-mg "tar" (ISO) products smoked under ISO regime

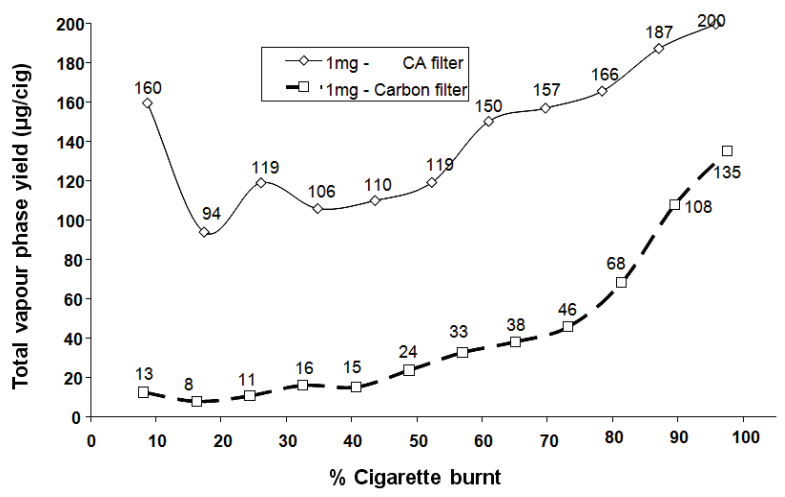

Appendix 6. 1-mg "tar" (ISO) products smoked under MA regime

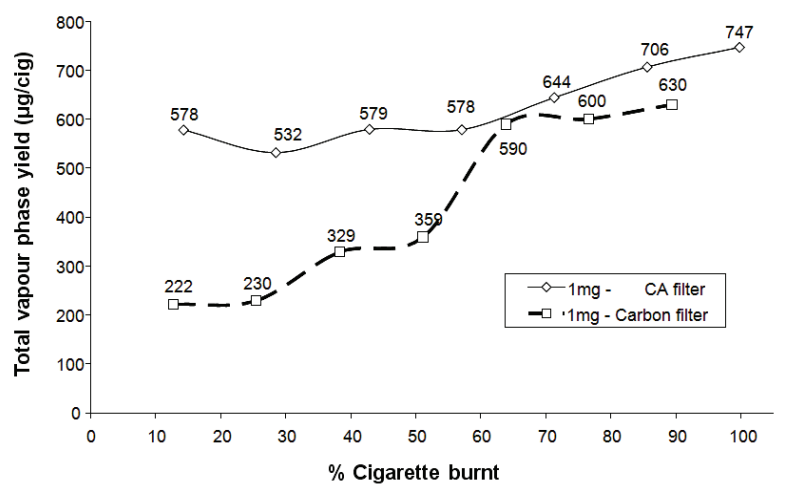

Appendix 7. 1-mg "tar" (ISO) products smoked under $\mathrm{Cl}$ regime 


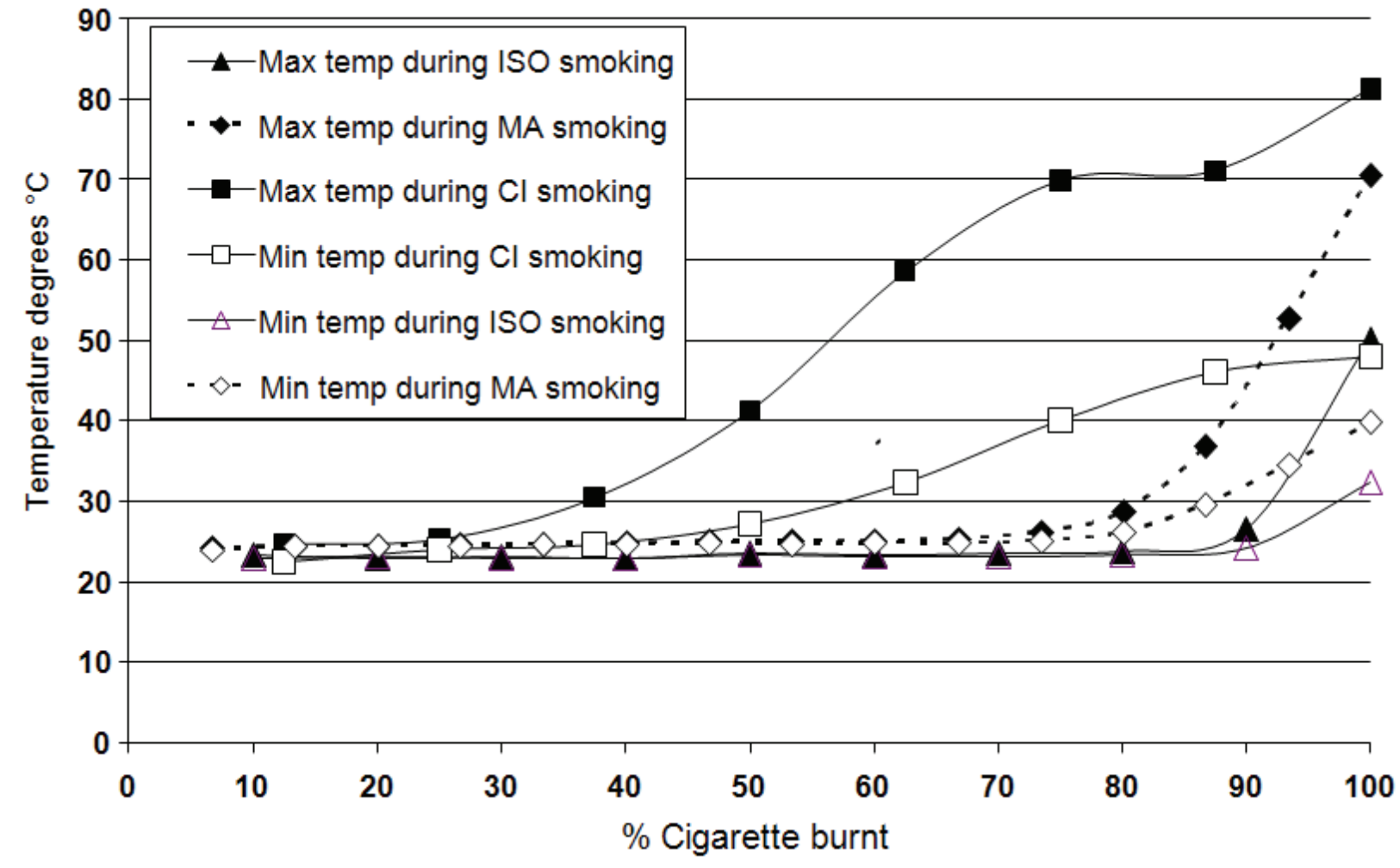

Appendix 8. Temperature profile for 1-mg "tar" cellulose acetate-filtered products, $20 \mathrm{~mm}$ from mouth end (equivalent to within carbon section)

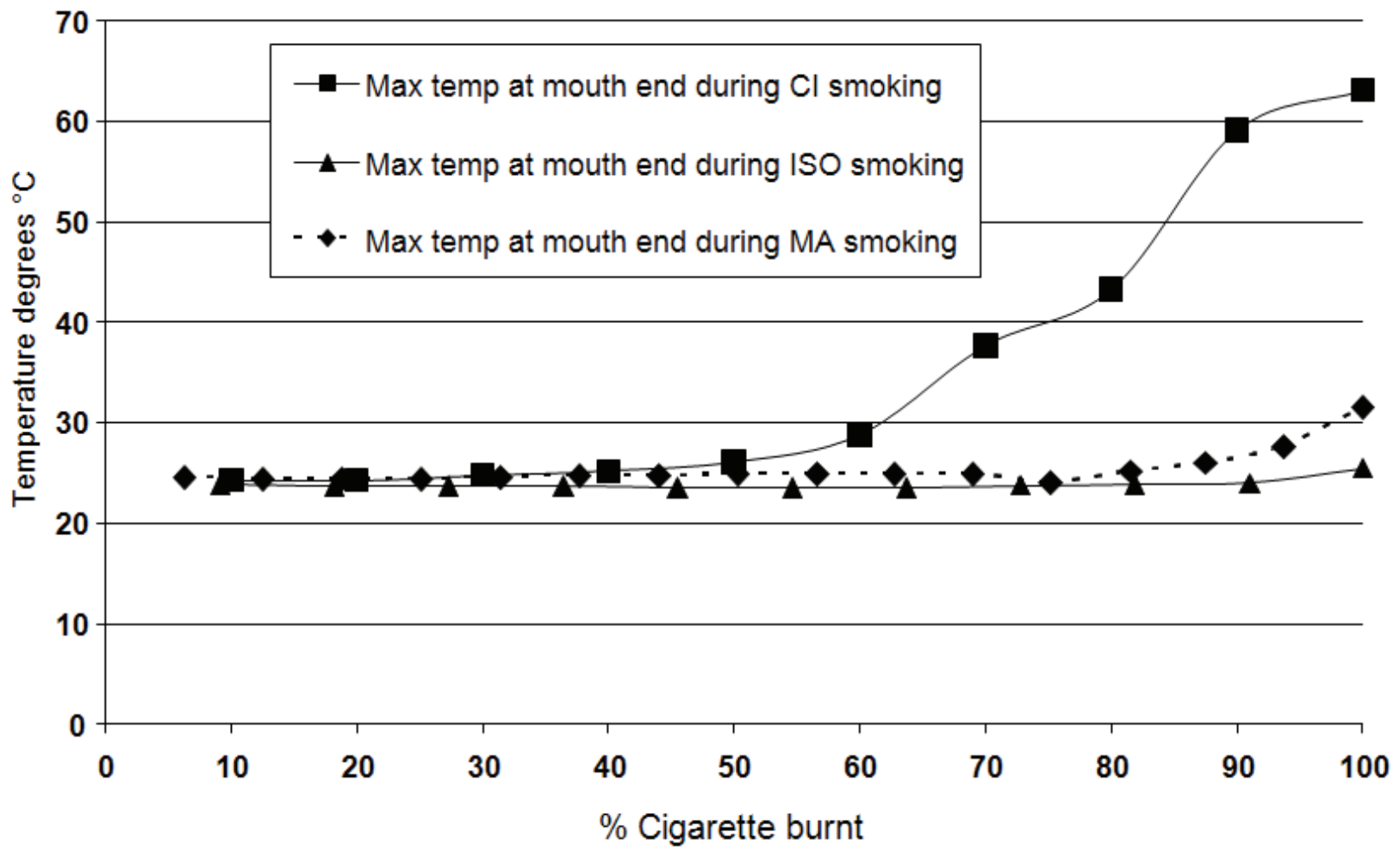

Appendix 9. Temperature profile for 1-mg "tar" cellulose acetate-filtered products, $5 \mathrm{~mm}$ from mouth end 
Appendix 10. Summary of vapour-phase reductions

\begin{tabular}{|c|c|c|c|c|c|c|c|c|c|c|c|c|}
\hline \multirow[b]{2}{*}{ Smoking regime } & \multicolumn{2}{|c|}{$Y_{\text {LIT END }}$} & \multirow{2}{*}{$\begin{array}{c}\mathrm{Y}_{\mathrm{CA}} \\
\text { Yield } \\
(\mu \mathrm{g}) \\
\end{array}$} & \multicolumn{2}{|c|}{$Y_{\text {DUAL }}$} & \multicolumn{2}{|c|}{$Y_{\text {CARB }}$} & \multirow{2}{*}{$\begin{array}{c}Y_{u v} \\
\text { Yield } \\
(\mu g)\end{array}$} & \multicolumn{2}{|c|}{$\mathrm{Y}_{\mathrm{RVD}}$} & \multicolumn{2}{|c|}{$\mathrm{Y}_{\mathrm{FV}}$} \\
\hline & $\begin{array}{c}\text { Yield } \\
(\mu \mathrm{g})\end{array}$ & $\begin{array}{c}\text { Conc. } \\
(\%)\end{array}$ & & $\begin{array}{c}\text { Yield } \\
(\mu \mathrm{g})\end{array}$ & $\begin{array}{c}\text { Conc. } \\
(\%)\end{array}$ & $\begin{array}{c}\text { Yield } \\
(\mu \mathrm{g})\end{array}$ & $\begin{array}{c}\text { Conc. } \\
(\%)\end{array}$ & & $\begin{array}{c}\text { Yield } \\
(\mu \mathrm{g}) \\
\end{array}$ & $\begin{array}{c}\text { Conc. } \\
(\%)\end{array}$ & $\begin{array}{l}\text { Yield } \\
(\mu \mathrm{g})\end{array}$ & $\begin{array}{c}\text { Conc. } \\
(\%)\end{array}$ \\
\hline \multicolumn{13}{|c|}{13 mg "tar" ISO } \\
\hline ISO & 3183 & 100 & 2177 & 1293 & 40 & 884 & 28 & 2177 & 1006 & 32 & 0 & 0 \\
\hline MA & 5937 & 100 & 4667 & 3381 & 57 & 1286 & 22 & 4667 & 1270 & 21 & 0 & 0 \\
\hline $\mathrm{Cl}$ & 6698 & 100 & 5462 & 4403 & 66 & 1059 & 16 & 5462 & 1236 & 18 & 0 & 0 \\
\hline \multicolumn{13}{|c|}{1 mg "tar" ISO } \\
\hline ISO & 2850 & 100 & 179 & 17 & 1 & 162 & 6 & 1105 & 1745 & 61 & 926 & 32 \\
\hline MA & 6429 & 100 & 1755 & 659 & 10 & 1096 & 17 & 5014 & 1415 & 22 & 3259 & 51 \\
\hline $\mathrm{Cl}$ & 5236 & 100 & 4262 & 3487 & 67 & 775 & 15 & 4262 & 974 & 18 & 0 & 0 \\
\hline
\end{tabular}

Measured yields and parameters

$\mathrm{Y}_{\mathrm{CA}} \quad=$ Machine Yield of cellulose acetate filtered cigarette

$\mathrm{Y}_{\text {DUAL }} \quad=$ Machine Yield of carbon-filtered cigarette

$\mathrm{Y}_{\text {LAST }} \quad=$ Yield generated in last cut-off puff

PN = Puff Number

Estimated yields

$Y_{\text {LIT END }}=$ Yield generated at coal (adjusted to $0 \%$ ventilation) $=Y_{\text {LAST }} \times$ PN $\times 100 /(100-F V)$ (where FV $=\%$ Filter ventilation)

$Y_{u V} \quad=$ Yield of cellulose acetate filtered cigarette (adjusted to $0 \%$ ventilation) $=Y_{C A} \times 100 /(100-F V)$

$Y_{C A R B} \quad=$ Yield lost to carbon filter adsorption $=Y_{C A}-Y_{D U A L}$

$Y_{\mathrm{FV}} \quad=$ Yield lost to filter ventilation $=Y_{\mathrm{UV}}-\mathrm{Y}_{\mathrm{CA}}$

$Y_{\text {RVD }} \quad=$ Yield lost to tobacco rod ventilation and diffusion (adjusted to $0 \%$ ventilation) $=Y_{\text {LIT END }}-Y_{U V}$

$Y_{\text {LIT END }}=Y_{C A} \times 100 /(100-F V) \times 100 /(100-R D V)$ i.e. $Y_{\text {COAL }}$ can also be used to work back to an estimate of \% RVD (where RVD = Tobacco rod ventilation and diffusion).

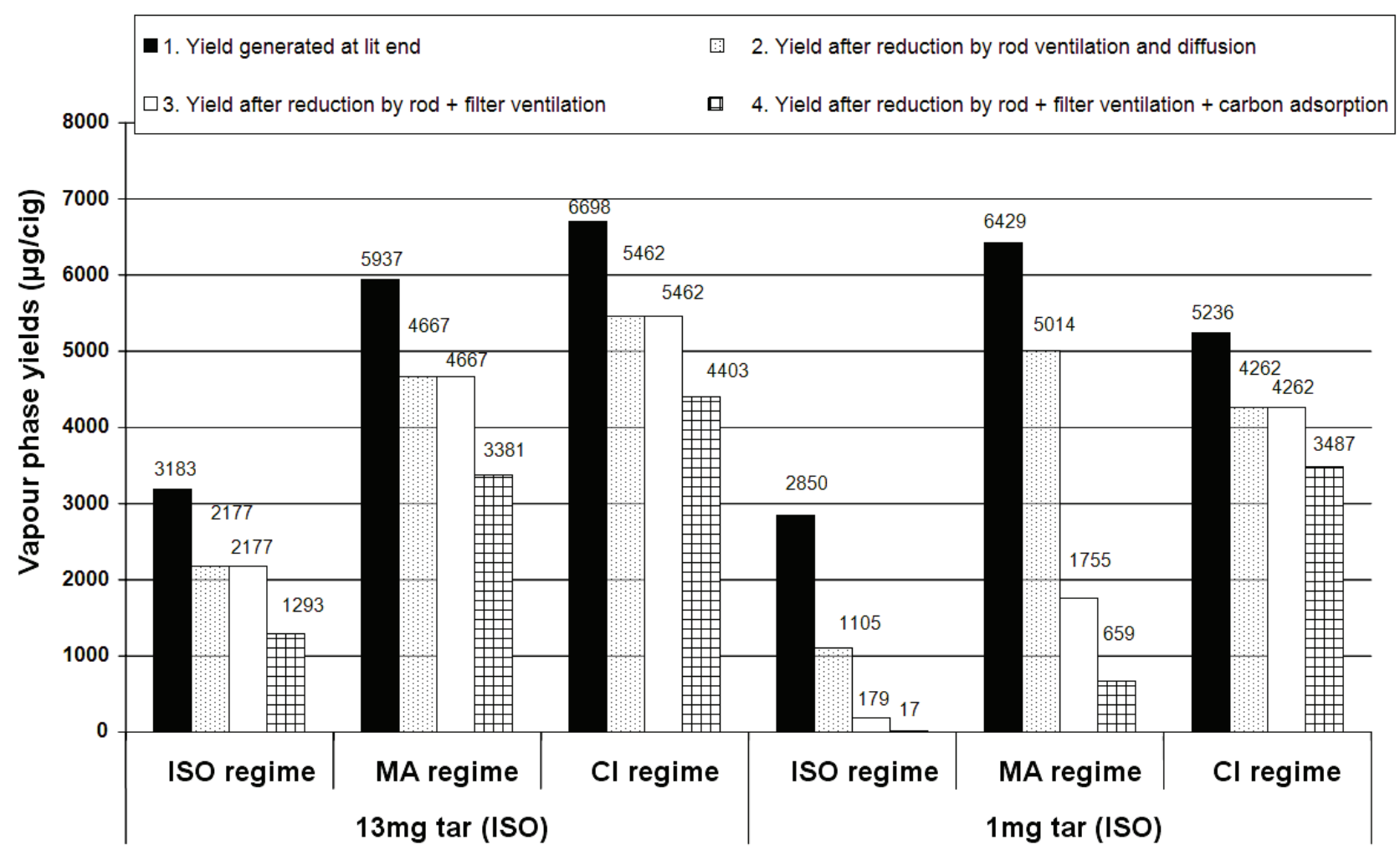

Appendix 11. Yield reductions by various cigarette design features 